УдК 316.334.56:394.014(571.17)

\title{
ГОРОДСКОЕ ПРОСТРАНСТВО КАК СЕМИОТИКО-МИФОЛОГИЧЕСКИЙ КОНСТРУКТ ВОСПРИЯТИЯ: МИФОЛОГИИ НОВОКУЗНЕЦКА
}

\author{
Пискунова Александра Евгеньевна, \\ alexpiskunova@mail.ru \\ Национальный исследовательский Томский государственный университет, \\ Россия, 634050, г. Томск, пр. Ленина, 36
}

Пискунова Александра Евгеньевна, магистрант кафедры антропологии и этнологии Национального исследовательского Томского государственного университета.

\begin{abstract}
Актуальность исследования определена устойчивым интересом социально-гуманитарных наук к пониманию пространственного измерения городской жизни, реабилитацией мифического как значимой культурной реалии современности, а также необходимостью понимания практических проблем восприятия городского пространства, характерных для конкретных российских городов. Цель работы: выявить мифы и мифологии, которые определяют (ментальную) организацию восприятия пространства города. Методика: теоретико-методологической основой выступают феноменолого-когнитивный подход к пониманию образа городского пространства, а также семиотические и психоаналитические интерпретации мифа. Увиденное в реляционной перспективе пространство города рассматривается через когнитивно-семантические структуры, обуславливающие избирательность процесса восприятия. В рамках исследования проведен анализ интервью (собранных автором в апреле-августе 2019 г.) с жителями Новокузнецка (Кемеровская область), который позволил описать ключевые мифологии восприятия как содержания, возникающие в результате мифологизации городского пространства. Результаты. Показаны значение и роль мифологий восприятия для формирования классификационной модели пространственных явлений городской действительности. Формируемый человеческим восприятием образ пространства города определен как смысловая конструкция, отвечающая системе интерсубъективных значений и интрасубъективных смыслов городской картины мира. Полученные результаты позволили увидеть не только континуум актуальных мифологических представлений о пространстве Новокузнецка, но и идентифицировать, какое значение имеют пространственные содержания городской жизни для конституции социально-культурных действительностей. Выявлено, что мифотворческая активность субъектов городской жизни обнаруживается как стремление к миропорядку, которое отвечает базовой человеческой потребности в стабильности и гармонии.
\end{abstract}

Ключевые слова: Миф, мифология, городское пространство, конструкт, восприятие, Новокузнецк.

\section{Введение}

Последние несколько десятилетий отмечены повышенным интересом социогуманитарных дисциплин, таких как география, история, культурология, социология, антропология, философия, к изучению города и населяющего его общества. Настойчивые попытки сформулировать понимание городской жизни сложились в междисциплинарное исследовательское направление, получившее название «городские исследования», или urban studies. Сомкнувшись с «пространственным поворотом» (spatial turn) [1], который воплощает оживленный интерес к изучению пространственного измерения со- 
циальной жизни, продолжительное время преобладающий анализ феномена города через призму темпоральной логики сегодня сменяется акцентуацией пространственных характеристик. Данное обстоятельство позволяет обратить внимание на не обозначенные ранее такие составляющие «городского», как связь между географическими данностями (физическими, материальными, вещественными) и социокультурными феноменами (воображаемыми, духовными, символическими) городского пространства, вопросы о его структуре, организованной различными (географическими, экономическими, социальными, ментальными, эмоциональными) контекстами [2]. В настоящее время в исследованиях города возрастает значение субъективной составляющей, когда городское пространство мыслится не только как историко-географическая и политикоадминистративная реальность, являющаяся выражением социальной организации общества, но как устойчивый социальный конструкт, часть воображаемой географии, определимая через смысловые и знаково-символические структуры [3]. Таким первичным способом концептирования и построения городской картины мира является миф как локальный опыт сознания, как его определенная конфигурация, которая активно функционирует в современности.

Кроме того, актуальность исследования мифологического восприятия городского пространства определяется потребностью в изучении и решении характерных для конкретных российских городов проблем, связанных с размыванием территориальной идентичности и потерей уникальности городского пространства, а также вызванных необходимостью развития пространства города. Социальные процессы в российских городах напрямую связаны с социально-экономическими преобразованиями, в рамках которых усиление межгородской конкуренции и необходимость эффективного городского развития сопровождаются превращением нематериальных ресурсов в один из основных источников устойчивого роста. Обращение к мифологическим представлениям связано также и со спецификой российских городов как постсоветских, развитие которых в настоящий период представляет собой трансформацию более или менее гомогенной социально-территориальной структуры в дифференцированную пространственную организацию. В результате формируется новый пространственный порядок, требующий для своего изучения особого исследовательского подхода и нового инструментария.

Итак, настоящее исследование сфокусировано на понимании того, что есть городское пространство как семиотико-мифологический конструкт восприятия. На примере города Новокузнецка (Кемеровская область) делается попытка осмысления мифов и мифологий как способа (ментальной) организации восприятия пространства города.

\section{Миф как принцип восприятия городского пространства: теория и методы исследования}

На современном этапе исследовательской разработки городской проблематики очевидна необходимость перехода к реляционному мышлению. В социопространственной перспективе город - социальный конструкт, а производство городского пространства предстает как множественный и динамичный процесс социальной жизни [4]. Трактовка города как процесса постоянных и непрерывных смысловых взаимодействий позволяет увидеть урбанистическое пространство в коммуникативной оптике, нуждающееся в комплексном пространственном осмыслении подвижности смыслов и символов. При этом смысл пространства формируется в опыте, в процессе человеческого восприятия и отношения к предметам объективного мира. Идея о трансформации реально наблюдаемых элементов городской среды в ментальные конструкты пространст- 
венных образов является одним из главных тезисов географии восприятия (perceptual geography), оформившейся в западной научной традиции в 1960-70-х гг. [5]. Признавая важность и значение телесных ощущений в восприятии пространства, перцептивной стороне субъективного опыта данная работа будет посвящена в меньшей степени, а основное внимание уделено восприятию как когнитивному процессу конструирования городской реальности посредством придания значимости её отдельным фрагментам, обусловленному как целями актуальной ситуации, так и предшествующим социокультурным и коммуникативным опытом [6]. Вышесказанное побуждает рассматривать образ восприятия городского пространства как некоторый социокультурный проект. Поэтому размышляя об образе города, мы говорим скорее о представлениях, когнитивных структурах или закодированных системах, задающих форму восприятия города, его видения, а значит, и способы действования. Чтобы понять субъективность и ее последствия, которые материализуются как человеческие действия в пространстве-времени, подходящим аналитическим ресурсом является так называемое «ментальное» или «воображаемое» пространство [7]. Городское воображаемое [8] есть ситуативное и фиксированное на городе сознание, ментальное и когнитивное картографирование городской реальности, которое воздействует на повседневную жизнь, являясь интерпретативными координатными сетями, согласно которым люди мыслят о чем-либо, знают по опыту, оценивают и действуют в местах, пространствах и коммуникациях [9]. Сфера воображаемого основана на том, что жители города ведут символическое существование, т. е. обладают некой общей системой значений. Конструируемый образ места есть сложная система наложившихся друг на друга смыслов, контекстов, представлений, порожденная латентными и непрерывными интерпретациями горожан окружающего их пространства в процессе своих повседневных практик.

Следует сделать акцент на том, что важной характеристикой городской среды является интерпретативность, т. е. ее семантический характер и предметность знаков и коммуникативность значений и смыслов, которыми она обладает. Одним из способов понимания и интерпретации окружающего мира является миф как структура и опыт сознания и деятельности [10]. Мифологический принцип уже давно выступает в качестве урбанистической парадигмы [11], задавая восприятие города как особого мифологического текста [12]. В своей работе мы в гораздо большей степени будем опираться на теорию современных мифологий, нежели на исследования традиционных архаичных мифов. Принимая во внимание полисемантичность сферы мифического и концептуальный плюрализм в интерпретациях мифа [13], для данной работы релевантным является соединение семиотического и психоаналитического подходов, которые в наибольшей степени соответствуют разработанной аналитической модели восприятия городского пространства.

С одной стороны, психологический контекст может многое дать для прояснения специфики мифологического восприятия городского пространства, поскольку представляет собой результат работы индивидуального и коллективного сознания, а разного рода аффекты и произвольные ассоциации, еще не получившие вербального оформления, являются важной составной частью процесса мифотворчества. С другой стороны, механизмы городской культуры, определяющие процессы интерпретации текстов, и повседневная жизнь горожанина как производителя смыслов являются областью, аутентично исследуемой структуралистской и семиотической традицией.

В формировании методологической позиции автора большую роль сыграли работы Р. Барта по семиологической проработке мифа и Ж. Лакана по структурному психоанализу. Р. Барт называет миф «вторичной семиологической системой» [14, с. 271], по- 
скольку он создается уже на существовавшей ранее семиологической цепочке - означаемое, означающее и знак как итог соотношения первых двух элементов, где знак первичной системы оказывается всего лишь означающим для вторичной. Миф, как и всякая семиологическая система, есть система ценностей, однако благодаря своей главной функции - натурализации, он прочитывается как система фактическая. Миф не отрицает вещей - он говорит о вещах, делая их ясными, но не объясняет их, а всего лишь констатирует. Этим может быть обоснована особая устойчивость стереотипов, например в образе промышленного города, где завод становится символом города, узнаваемым, понятным и привычным [15].

Базовым тезисом психоаналитической теории Ж. Лакана является утверждение языковой природы бессознательного [16]. Субъект реализует себя через речь, а функция речи основывается на существовании связанного с бессознательным Другого как особого порядка, вынесенного исключительно в сферу чистого символического и надэмпирического [17]. У Лакана Другой не является гомогенным понятием: фундаментальным для аналитической практики является разграничение Другого, общий символический вектор человека, его сконцентрированное чувство зависимости, и другого, который подменяет первого, недостижимого и приводит к созданию проекции своего Я на внешние объекты. Другой обозначает радикальную инаковость, отделенную, самостоятельную сущность, непостижимое не-Я.

В связи с этим второй важный тезис Лакана: бессознательное есть дискурс Другого, который организует означающие. Другим, как субъектом бессознательного, оказывается дискурс большинства, способ выражения глубоко интимных аспектов внутреннего опыта с помощью укоренившихся в культурном универсуме значений и смыслов. Е.К. Малая [18] в результате применения приемов структурного психоанализа определяет в качестве классических признаков присутствия идеи Другого в опыте переживания города вычитывание в урбанистическом пространстве целостного одушевленного образа, выражающего себя через определенную знаковую систему, обладающего властью над сферой желаний человека и связанного с бессознательными интенциями.

С учетом вышесказанного под мифом как принципом восприятия городского пространства будем понимать когнитивный процесс конструирования пространства города посредством придания значимости его отдельным фрагментам, результатом которого является формирование мифа как вторичной семиологической системы, в которой может вычитываться психический опыт городских субъектов, структурируемый ориентацией на символического Другого и его желание. При этом многообразие мифов образует когнитивно-семантические структуры, обладающие значительным рецептивноинтерпретативным потенциалом. Таким образом, мифологию восприятия городского пространства определим как систему мифов, отражающую организованные вокруг некоторой доминанты территориально структурированные представления горожанина, которые образуют сеть или слой в ментальной картографии человека.

Происходящие в последние несколько лет изменения Новокузнецка позволяют по-новому взглянуть на взаимосвязи физического и символического/воображаемого пространства. Выбор данного объекта исследования обусловлен не только тем, что Новокузнецк является типичным индустриальным городом, развивающимся на постсоветском пространстве, а его социокультурное пространство остается на сегодняшний день малоизученным. Специфику данному случаю придает прошедшее в 2018 г. празднование четырехсотлетнего юбилея города, которое актуализировало обсуждение стратегии развития города, работу по созданию его нового образа, а также стимулировало множество проектов реконструкции в городской среде. При этом одним из важнейших по- 
следствий активных трансформаций городского пространства является формирование у горожан новых пространственных представлений, которые, по нашим предположениям, формируются в соответствии с семиотико-мифологической логикой.

Разнообразие локально-мифологических представлений образует единую социокультурную реальность города, которая актуальна и адекватна как коллективным представлениям абстрактного городского сообщества, так и отвечает субъективной размерности городского пространства. В данной работе мы сфокусировались на том, что другие исследователи городской мифологии называют «мифотворчеством снизу», спонтанной и естественной мифологизацией явлений городской жизни. Для решения поставленных задач анализ проводится на материале 21 полуструктурированного интервью с жителями Новокузнецка, собранных автором в апреле-августе 2019 г.

Поскольку различные части городского пространства в ментальном поле могут иметь множественные схемы концептуализации и интерпретации, то некоторые локальности не единожды упоминаются в различных контекстах, образуя тем самым аналитическую модель места как палимпсеста, разрабатываемую в рамках мифогеографии (И.И. Митин).

Далее представим анализ и интерпретацию материала в виде описания мифологического пространства города, которое составляют индуктивно и апостериорно выделенные мифологии восприятия, бытующие на уровне «мифотворчества снизу».

\section{Мифологии восприятия пространства города Новокузнецка}

Город Новокузнецк является типичным индустриальным городом, содержащим в своем ландшафте три основных хронотипа: историческое наследие дореволюционного времени («Кузнецк», представленный несколькими зданиями конца XVIII - начала $\mathrm{XX}$ вв.), индустриальное наследие («Сталинск», сложившийся в советское время) и современное наследие, формирование которого связано со многими проектами реконструкции и новой застройки.

При этом Новокузнецк является убедительным примером того, как на постсоциалистическом пространстве в семиотико-мифологической конкуренции побеждает мощный комплекс советской семантики. Это порождает в восприятии городского пространства и города в целом многообразие ориентированных на общую доминанту мифов, в совокупности образующих мифологию советского.

Рецепция советского в городском тексте культуры имеет различные основания [19]. В частности, «советскость» вычитывается в архитектурном облике города, который также семантически неоднороден. Во-первых, это «соцгород» или конструктивистские здания как особый стиль, который относится к сталинскому периоду застройки: величественный, добротный, когда каждое здание имеет свой, отличный от других архитектурный замысел. Образы восприятия вызывают в сознании горожан представления о реалиях повседневной социалистической жизни, а именно об обыденных практиках и некоторых коммуникативных особенностях «советских людей», которые кажутся специфически «советскими» и расцениваются как социокультурная утопия. Подобные переживания есть тоска не по государственной системе или идеологическим ритуалам, а по таким во многом утраченным ценностям советской жизни, как бескорыстие, равенство, искренность и непосредственность, радушие, порядок, уют, относительная неважность материальной стороны жизни, забота о будущем и других людях. В ностальгическом порыве обнаруживается фоновое мифологическое содержание, когда советское прошлое начинает восприниматься некритично, сверхпозитивно, идеализированно - как 
лишенное сегодняшнего травмирующего опыта, целостное и полноценное (в смысле наполненности себя собственной сущностью).

Второй тип «советской» архитектуры - «хрущевки», появившиеся в период массового жилищного строительства, - идентифицируется как разрушающееся и устаревшее наследие ушедшей эпохи, серое, и поэтому унылое. В реалиях современных городов символический капитал этих архитектурных объектов составляет чувство отчуждения, бессмысленности, лжи и цинизма, присущее не только некоторым сторонам советской действительности, но и сегодняшней городской жизни.

В восприятии города актуализируется социалистическая индустриальная мифология, содержательно выражающая преодоления, успехи и рекорды на пути построения коммунизма. Вершиной логики индустриального проектизма является завод, материализованный лозунг и перформативный жест советского (социокультурного) ландшафта. При этом большие размеры завода метонимически представляют мощь и размах не только его строительства и функционирования в советский период, но и в целом идеолого-символическую сферу эпохи. Кроме того, огромное в ландшафте вызывает чувство удивления и восхищения, завод - предмет гордости современников. Такое совершенно особенное отношение к заводу и к тем подлинным горожанам, которые не одно поколение трудятся на заводе для благополучия города и страны (особенно в период Великой Отечественной войны), порождает мифологию генетического родства, будто «заводское» прошлое жителей на уровне генов определило их стать, мощь и самоотверженность: «Для меня это ... символ города ... это вот гудок 8 утра из КМК [Кузнецкий металлургический комбинат - А.П.]. Он невидимый, но это символ для меня, да. Ну не знаю, наверно, потому что первое поколение ... они металлурги были, как-то это с кровью передается» (Ж, 21, учеба). (Здесь и далее в скобках указаны социальнодемографические характеристики информантов - пол, возраст и род деятельности соответственно.) Фигура заводского рабочего, как архетипического пролетария и настоящего человека, особая трудовая этика промышленного производства становятся частью операционального определения ценной социальной идентичности горожанина.

Функционирование завода понимается как общественная ценность: это ключевой актант в развитии города, обеспечивающий благополучие современного Новокузнецка. Поскольку завод остается значимой экономической реалией города, потенциальные экономические эффекты его деятельности способствуют более лояльному восприятию негативных последствий и иногда даже оправданию производственных издержек (выбросов, загрязнений). Экономическая зависимость от деятельности промышленных предприятий сделала новокузнечан способными на почти героическую форму уступчивости и большую терпимость к экологической несправедливости: «Не знаю, я $\kappa$ этому [к загрязнениям - А.П.] как-то спокойно отношусь: я это знаю, я это принимаю. Это неотъемлемая часть производства, по сути» (Ж, 21, учеба).

В восприятии горожан содержится принципиальная двусмысленность городской традиции понимания деятельности завода: с одной стороны, это полезный и героический труд, а с другой - регрессивный и отсталый. Промышленное прошлое города является не только объектом наследия и отвечает за богатство и чувство превосходства, но при альтернативном прочтении становится оковами на будущих возможностях и траекториях развития Новокузнецка. В такой перспективе промышленное производство в целом воспринимается как «старое», создающее культуру зависимости, лишенное инноваций и гибкости. При этом для восстановления нормативной среды городской культуры и поддержания коллективной идентичности негативное восприятие городского прошлого сочетается с идентификацией вины и выражается в провинциальных ресен- 
тиментах - чувстве враждебности к «незаслуженной» столице области (Кемерово), к региональным и федеральным администрациям, которые в представлениях городских субъектов являются причиной городских неудач, и сопряженном ощущении бессильной зависти и тягостном осознании тщетности попыток повысить статус Новокузнецка и качества жизни в нем: «Сразу понятно, что на нас как бы забили уже массово. Обидно. Я так думаю, что именно и правительство, и государство как-то ну ... Им не интересно, чтобы мы тут развивались, потому что все равно все деньги идут в Кемерово. Кемерово еще как-то что-то развивается, а мы нет» (Ж, 24, работа в коммерческой организации). (Здесь и далее: выделения в фрагментах интервью сделаны автором.)

В реалиях Новокузнецка мифология советского в своих основных чертах воплощает фигуру лакановского Другого, представленного символическим порядком советских идеалов и ценностей. Императив унаследованных от советской эпохи символических структур, определяющий способ восприятия советской жизни как добротной, правильной, мощной, обуславливает развитие городской системы на постсоветском пространстве в заданных смысловых траекториях. Принципиальная инаковость, недостижимость Города-Другого при этом становится объектом желания горожанина, составляет сконцентрированное чувство его зависимости.

Некоторые части пространства города в представлении жителей характеризуются как «настоящие», «истинные», «неподдельные», выражением чего является мифология аутентичности, которая актуализируется для субъективной «обработки» различных проявлений стремления к «подлинности» как особому региону жизненного опыта. Такие городские пространства в восприятии горожанина отличаются непосредственной убедительностью, ощущаются как свободные от фальши, дурной подражательности. Воображаемое «путешествие в прошлое» через опыт аутентичного является экзотикой для новых поколений, выросших в посткоммунистическое время. Для них необычность «встречи с подлинным» ощущается в большей степени в отношении тех мест, которые физически, материально отличаются от обыденно наблюдаемых или предполагают включение в виды деятельности, не схожие с повседневными практиками: «Там [кинотеатр «Октябрь» - А.П.] все равно, какой-то антураж, там вот эти стульчики как в театре, такие старые, деревянные, то есть в обычных кинотеатрах, в современный, ты ходишь с детства, для тебя что-то нового не происходит, а тут я-бах попала как будто в параллельную вселенную. И винтаж: вот я вообще люблю все старое, мне очень нравится вот это. Там и такие, знаешь, ... бабушки эти, которые и продают тебе билетик, а билетик такой маленький!» (Ж, 20, учеба).

При этом в условиях постиндустриальных трансформаций городского пространства происходит символическая эксплуатация некоторых мест, когда городским сообществом совместно конструируются и репрезентируются некоторые культурные объекты и пространства в качестве аутентичных. В этой практике выражаются стремление к удовлетворению желания горожан пережить аутентичный опыт и невозможность «реального» обретения состояния «подлинности жизни». Восприятию города в данном случае сопутствует появление фантазма аутентичности места, который обнаруживает стремление к реализации некоторого желания, определяемого в лакановской логике через нехватку. В результате «аутентичность», как интерпретативный прием восприятия, становится проекцией собственных ожиданий, предпочтений и стереотипных образов горожанина на воспринимаемые объекты и места городского пространства.

Усилия городской элиты по навешиванию «ярлыка» подлинности сопровождаются, согласно концепции Д. Маккеннелла, появлением в городском пространстве точек 
«постановочной аутентичности» [20]. Конструируемая сверху аутентичность мест, которая, как мифологический конструкт, характеризуется искусственной причинностью, разоблачается жителями на повседневном уровне, вскрывая стремления по «созданию подлинности»: «Просто это [Кузнецкая крепость - А.П.] всем навязанный культурный символ города: его пихают везде, где только можно, и она только одна на слуху в основном. Я считаю, что это раскрученное место. Меньше хайпа ей бы. Ну в общем, действительно, ее слишком много везде пихают, она прям повсюду. Не дают никаким другим местам Новокузнецка стать новокузнецкими» (Ж, 37, работа в коммерческой организации).

На аутентичность городских пространств трансформирующее влияние оказывает туризм, мощный социокультурный и экономический феномен, в наибольшей степени аккумулирующий основные тенденции постсовременного потребления. Некоторые ландшафты городской культуры стали переориентироваться на туристский рынок, эксплуатироваться в коммерческих целях, лишаясь при этом социально-исторической основы, видоизменяясь, упрощаясь. В этом смысле коммодификацию можно рассматривать как уничтожение аутентичности самого местного сообщества, его культурных продуктов и отношений, приводящее к формированию «постановочного» или фальсифицированного опыта, создаваемого специально для внешних потребителей.

Чувственное восприятие выразительных форм городской среды инициирует появление эстетического измерения пространства. Эстетическое освоение городских пространств устремлено к глобальным означаемым, пропитанным эмоциальноценностными представлениями, и именно символические элементы окружающей среды вызывают эффект мифологического восприятия. Например, массовая застройка, «просвечивающая» советский ландшафт, который (был) безличностно-коллективен, и недостаточная работа городских властей над улучшением и гармонизацией визуального облика города формируют дефицит эстетического опыта. Новокузнечане, как и многие другие жители городов на постсоветском пространстве, существуют в условиях ландшафта, окрашенного в мрачно-серые оттенки (серые одинаковые стены домов, покрытые трещинами, серый асфальт).

Мифологическая эстетизация города происходит через категории красивого и прекрасного. Красивое служит выражением совершенства, гармоничным сочетанием различных аспектов городского пространства, которое вызывает у наблюдателя эстетическое наслаждение. Как наивысшая эстетическая ценность прекрасное претендует на целостность и конечность; при встрече с прекрасным в пространстве горожанин имеет дело с желанием завершенного и в этом смысле абсолютного. Подобную эстетическую интенциональность приобретают места наложения природных и антропогенных объектов: зеленых насаждений, скверов, водоемов. Горожанин интуитивно стремится к близости с природой, она становится одним из доступных источников творческого вдохновения в условиях унылой городской повседневности. Другим выражением прекрасного в пространстве города являются религиозные сооружения (храмы, церкви), эстетические и геометрические каноны которых позволяют мифологическому сознанию углубиться в складки некоего врожденного (архетипического) знания и дают возможность человеку ощутить восхищение и трепет.

Кроме того, при восприятии некоторых локусов города возникает чувство возвышенного: это впечатляющие городские формы, с которыми наблюдатель сталкивается неожиданно, оказываясь в месте, далеком от его однообразной повседневности и, как правило, уединенном. Исключительность возвышенных пространств бывает двоякого рода: внешнего масштаба, превосходящего привычную норму чувственного воспри- 
ятия, и внутренняя, смысловая, постигаемая интеллектуально [21]. Городское возвышенное, по сути, есть аффект: это место, где разыгрывается драма, которая отчасти проистекает из масштабов представленных в ней явлений.

В пространстве Новокузнецка примерами возвышенного в его классической трактовке являются густые рощи, широкие реки, глубокие озера, высокие холмы. Однако возвышенное не ограничивается собственно природой: источником глубокого эстетического переживания становится религиозная архитектура, величественные соборы и храмы, поражающие горожанина своими размерами и монументальностью.

Городской формулой возвышенного в пространстве Новокузнецка оказывается завод. Являясь материальным и символическим наследием советского периода, завод позволяет в эстетическом опыте ощутить универсальность и тотальность властносиловых отношений; он есть выражение мужского начала, подлинной (пролетарской) маскулинности. Восприятие завода сопровождается доминированием таких эмоциональных переживаний, как ужас и трепет, сочетание ужаса с радостью. Завод как опыт возвышенного приравнивается к травме: огорчение и удовольствие характеризуют то субъективное состояние, которое одновременно сопутствует и памяти о месте, и ее вытеснению. Его можно признать своеобразной архитектурно-инженерной синекдохой: символом прошлого, многолетнего существования, а иногда также видоизменения, созидания, чувства гордости. Возвышенное как особый модус мифологического восприятия вызывает у горожанина осознание долговечности завода, его «длительности» и мысли о преходящем характере своего собственного существования, о непрочности жизни и о неизбежности конца: «А вот КМК, вот это вот Новокузнеик ... потому что вокруг него все строилось, вокруг него люди умирали» (Ж, 21, учеба).

Современный город представляет собой сложное поликодовое образование; городской текст культуры содержит комбинации кода естественного языка с элементами других семиотических систем. В связи с этим город является и полимодальным текстом: познавательные потенции эстетического опыта формируются на базе различных сенсорных каналов восприятия. Эстетическое Новокузнецка составляют не только визуальные образы, но и звуковые явления городского пространства - конкретные звуки (например, заводской гудок) или музыкальные фрагменты (например, церковное песнопение).

В эстетический опыт современного горожанина включаются те пространства, которые благодаря усилиям культурной политики и имеющимся в распоряжении городского управления инструментам формирования новой городской среды становятся жестами преодоления индустриального «синдрома». Паблик-арт (поддержанный муниципальными программами) и элементы стрит-арта воспринимаются не только как стремление украсить гомогенное пространство и обогатить городскую среду визуальными элементами, но в акте смотрения присваиваются жителем как попытка преодолеть отчуждение от визуальной городской среды.

Однако в условиях перенасыщенного медиа пространства, когда в ходе украшения к уже существующей интенсивной материальности городской жизни добавляются новые элементы, многие эстетические преобразования воспринимаются как интервенции в визуальное тело города [22]. В таком фокусе эстетизация городского пространства становится неуместной и избыточной, приводящей не к оригинальности, а к безвкусице, преобразующей порядок в хаос, целостное - в аморфное. Основной причиной нарушения норм визуальной экологии является преобладание в публичном городском пространстве агрессивных образов, таких как рекламные щиты, объявления, цветодинамическое освещение, отличительными свойствами которых являются неожидан- 
ность, броскость, внезапность. Такие образы, которые не просто окружают, но бросаются в глаза, завладевают вниманием человека, в «эстетике порядка» превращаются в образцы визуального загрязнения.

Эстетизация урбанистического ландшафта во многом обусловлена художественными способностями горожанина, что означает осуществление не только эстетического восприятия и переживания явлений городской действительности, но и создание собственных художественных ценностей в определенном виде искусства (преимущественно в изобразительном искусстве, литературе и музыке).

Критерием эстетического «захвата» городского пространства становится фотогеничность мест, т. е. их характеристики, благоприятные для воспроизведения на фотографии. В практике фотофиксации мест они лишаются собственных значений, в визуальном городском обороте воспринимаясь в фрейме достопримечательности. Ключевым объектом подобного потребления становится Кузнецкая крепость, узнаваемый знак, способный и представлять самого себя, и метонимически замещать весь город. Однако не только в туристской практике, но и в вернакулярных фотографических вояжах (например, свадебные фотосессии) съемка Кузнецкой крепости реализует так называемый «герменевтический цикл»: люди ищут те виды, которые они уже видели (в социальных сетях, по местному телевидению); далее они фотографируют эти виды уже сами и затем показывают снимки своим знакомым.

Некоторые места города могут не только сами являться источником эстетического опыта, но позволяют обеспечить доступ к этому опыту: «Когда приезжают к нам в гости знакомые, мы водим их на эту крепость [Кузнеикую - А.П.] из-за смотровой площяадки. Она позволяет оченить, что из себя представляет Новокузнецк» (Ж, 52, работа в коммерческой организации). Место становится удобной точкой для предельно широкого визуального охвата открывающегося пространства, который позволяет максимизировать впечатления от увиденного. Символическое «присвоение» города на таких снимках приобретает форму вуайеристской практики «любопытствующего подглядывания» за пространством, характеризующейся скопическим влечением, желанием видеть как можно больше.

Необходимость совместной жизнедеятельности в пространстве города и потребность в согласовании личных и общественных интересов актуализируют на мифологической оси восприятия духовно-нравственные ценности и идеалы, лежащие в основе морального регулирования поведения горожан. Этика как мифология позволяет обнаружить те идеи и идеалы, которые проявляются в отношении к людям и окружающей среде. Некоторые горожане фиксируют размывание, ослабление и релятивизацию морально-этических норм как регуляторов общественной жизни: «Хамло, люди, которые не понимают каких-то правил моральных. Люди, которые, вообще не воспитанные, у которых нет мозга» (Ж, 23, учеба).

Этикет, как установленный порядок и система требований, предъявляемых к поведению человека в различных частях городского пространства, становится одним из условий субъективной размерности городского пространства. Причем мифотворческая активность в этом случае преимущественно связана с ситуациями нарушения правил другими людьми, разделяющими пространственный опыт. «Недостаток воспитания» как семантический атрибут обозначенной мифологии содержательно относится к недостатку таких социальных качеств личности, как гражданственность, социальная активность, ответственность, и к несформированности гражданско-правовой и нравственной позиции, в том числе порядочности. 
При освоении жителями ценностно-нормативной стороны городской жизни общества неосознанная лояльность по отношению к доминирующим нормам и установкам воспринимается как ложная и даже порицаемая. В этой связи конформизм как особая форма поведения и взаимодействия городских субъектов, при которой человек или группа лиц демонстрируют движение в сторону принятия или соглашения с мнениями, установками, нормами интересующей их группы, рассматривается как одно из проявлений идейно-ценностного тупика общества потребления [23]. Агрессивно навязанные массовой культурой ценности воплощаются в использовании городских пространств, которое максимально соответствует поведению среднестатистического члена абстрактного общества потребления (например, в конвенциях свадебной фотосессии с четко определенными местами, ракурсами и эмоциями на снимках). При этом негативизм, попытки индивида решительно противопоставить себя группе, при любых обстоятельствах выступить против мнений, оценок, поведения большинства, становится частным проявлением конформизма, эксцессами социальных отношений в обществе, где господствуют ценностный релятивизм, клиповое сознание и мультикультурализм.

В восприятии человека городское пространство соотносится с порядком организации городской жизни, воплощением социальной структуры. Складывается особая мифология перехода, которая антропологически может быть понята через аналитику обрядов перехода. А. ван Геннеп [24], автор данной концепции, обратил внимание на широкое распространение однотипной символической структуры в так называемых обрядах перехода (среди которых рождение, инициация, брак, смерть), которые оформляют переход человека или группы людей из одного (социального) состояния или места в другое. В жизненном цикле человека каждый обряд перехода состоит из трех связанных фаз, представленных самостоятельными прелиминарными (отделение), лиминарными (переход), постлиминарными (включение) обрядами. Сначала человек (или группа людей) отделяется от привычного социального окружения, затем проходит период изоляции (очищение от следов прежней жизни и прохождение через испытания), а затем включается в новое социальное окружение либо в старое, но в каком-то ином качестве (сопровождается обретением новых знаний, нового имени и признанием новыми сообществами). Всякое изменение в положении человека представляет собой возмущение порядка в социуме, и функция обрядов перехода - восстановление общественного равновесия и смягчение нежелательных для коллектива эффектов.

В пространственных категориях одним из вариантов перехода являются обряды, сопровождающие перемену места жительства или места временного пребывания. Они функционируют как системы символов и в первую очередь связаны с материальностью городского пространства, где определенные места или объекты маркируют воображаемую границу территорий. Знаки пересечения городской черты Новокузнецка коннотативно увязаны с идентичностью, некоторым чувством города: «Символом назову стелу Новокузнецкую, потому что это та граница, хотя это не территориальная граница, потому что Новокузнецк раньше-то начинается. Но это именно тот символ, тот знак, который обозначает, что именно сейчас всё - ты в Новокузнецке, ты в Новокузнецке, а не где-то там» (M, 34, работа в коммерческой организации).

Лиминарность проявляется в конкретных «пограничных» местах: путешествуя из города в город, на пути человека непременно оказывается вокзал, аэропорт или автобусная остановка: «Это, знаешь, точка отсчета вот: центр для меня города - это вокзал, несмотря на то что он как бы на периферии находится. Для меня это иентр, потому что туда приезжают поезда и оттуда отправляются в другой опять город, именно все путешествия ты начинаешь от вокзала» (Ж, 20, учеба). В состоянии пере- 
хода ощущения человека обостряются, нередко возможны чувство страха или ощущение дискомфорта.

Обряды входа и выхода, сопровождающие покидание и возвращение в различные социальные пространства, воплощены в практике преодоления внутригородских границ, где границы административных и вернакулярных районов города маркированы особыми знаками, установленными в местах перехода, на дорогах и перекрестках. В мифологическом восприятии материальными символами входа и выхода являются выделяющиеся (например, большие, яркие, пустые или насыщенные социальными взаимодействиями) места и объекты, которые в процессе субъективного освоения городской среды становятся визуальными ориентирами: «Спасо-Преображженский собор просто такая церковь, которая стоит практически на входе в Кузнецкий район» (Ж, 33, работа в коммерческой организации).

Одним из обрядов перехода является инициация разного порядка, которая определяется включением человека в иное (воображаемое) сообщество с соответствующим экзистенциальным присоединением (смена моделей поведения, ценностей). Инициация открывает доступ не только в возрастные классы, но и отмечает социальную зрелость, например включение в религиозные сообщества и вступление в профессиональную деятельность.

В контексте настоящего исследования инициация в личной биографии связана с кардинальными переменами в субъективном опыте, предполагающими новые возможности для обживания и использования города. В первую очередь это проявляется в получении доступа к новым пространствам города, который связан со снятием родительского запрета: дальнейшее их освоение становится необходимым этапом взросления, который помимо прочего сопровождается формированием новых социопространственных практик: «Я вот так назову ТРЦ. Это связано с моим подростковым взрослением, и там произошел такой перелом моего мышления, замкнутого, когда я боялась народа, боялась, что меня осудят. <..> В ТЦ я сама, то есть ... прошла какой-то путь опыта, когда я из застенчивого подростка превратилась в более или менее спокойного» (Ж, 20, учеба).

Кроме того, ежедневные массовые пересечения внутригородских границ, главным образом из спальных районов на работу или для проведения досуга в городской центр, в мифологическом сознании тоже становятся своего рода инициацией. В логике мифа развитие образа мифологического героя, связанное с обретением силы или власти, обусловлено городом и реализуется в нем. Семиотически значимым оказывается в этой связи именно выход за пределы своего двора/района как пространства защищенного, который, кроме того, предопределяет и возвращение горожанина в новом статусе. Не менее важным в такой, совершаемой в координатах городского пространства, инициации является перемещение в конкретный топос как способ самосовершенствования, спасения и освобождения, например на работу, учебу, в церковь и пр.

С обрядами инициации пересекаются так называемые обряды первого раза. Восприятие первого раза, первого шага, почина имеет особую значимость для человека, поэтому в пространственных координатах города первое посещение мест потребления (например, торговых центров), религиозных сооружений, учебных заведений оставляет яркую точку в памяти и на ментальной карте горожанина.

Устойчивая пространственная практика сопровождает один из этапов другого обряда перехода, свадьбу. В реалиях современного города свадебный ритуал завершает традиционная свадебная фотосессия по его знаковым местам, своего рода «рождение» (тоже обряд перехода) новой семьи, инициация городом новой супружеской пары. 
В рамках лакановской теории новобрачные направляют свои бессознательные интенции к Городу-Другому, поскольку в человеческой жизни основное желание определяется желанием быть признанным (Другим).

В контексте города пространственное измерение также имеет умирание, когда первую фазу перехода из одного состояния (живой) в другое (мертвый), обряд отделения, составляет посещение определенного места. В этом случае мифологическое сознание горожанина актуализирует городские легенды, связанные с обитающими там мифологическими персонажами или с более абстрактными и неперсонифицированными угрозами, а также произошедшими здесь ужасающими происшествиями, например убийствами. Негативный потенциал фольклорных нарративов реализуется в том, что фольклорное знание заставляет ощутить травматические переживания, чувство страха и беззащитности. При этом в мифологическом сознании потенциальные угрозы связаны не с активностью людей, а как будто исходят из воли самого пространства: «Неоднократно слышиала, что около первой гор. больницы, там есть заброшенные, если я не ошибаюсь, здания и репутация такова, что были смертельные, к сожалению, случаи в этом здании. Что люди опять же непонятно по каким целям туда забирались, и заканчивалось это все летальным исходом. <..> Если проходить мимо гор. больницы, где это заброшенное здание, сразу становится, в связи с известными мне легендами, как-то немножечко не по себе, но что: а если тут действительно летальные случаи. Ой, да лучше я обойду стороной» (Ж, 37, работа в коммерческой организации). При этом субъективный опыт освоения подобных пространств города обязательно сопровождается остенсией, осуществлением каких-либо действий под влиянием фольклорного сюжета. В одних случаях прагматика мифа места связана с желанием проверить «правдивость» легенды, приобрести дополнительный символический авторитет, пройдя через пугающее действие, или получить новые впечатления, недоступные в городской повседневности. Другой способ реализации остенсивного действия - избегание мест с «плохой репутацией», вытеснение, сублимация страха через пересказ друзьям и знакомым.

Особый субстанциальный переход отмечен пространственными представлениями одного из информантов о Кузнецкой крепости, где произошедшее событие сопровождалось несколькими изменениями в экзистенциальном положении вещей: «Там произошел случай несчастный, тоже с молодоженами: поженились, после загса поехали фотографироваться, и невеста падает и умирает. <...> ну представь, свадьба, такой момент, новая семья. И бах - девушка умирает. Даже знаешь, какой-то там магический, наверное ... почему-то же она там упала, хотя несмотря на то, что там не очень-то и высоко было, но она упала и разбилась. Это магия, что-то там не то» (Ж, 20, учеба). Здесь для брачующихся произошел переход от одинокого, холостого положения к семейному, для невесты посещение места стало границей между жизнью и смертью, для жениха - между статусом мужа и вдовца. Можно отметить и косвенный переход, произошедший с узнавшим об этой истории информантом, у которого изменилось отношение к месту. Мифологическую актуализацию данного сюжета можно рассматривать как своего рода постлиминарный период перехода, когда место приобретает новый субъективный смысл и встраивается в актуальную мифологическую картину мира горожанина.

Осевой нитью для одной из групп пространственных мифов является семиотическая оппозиция «верх/низ», на символическом уровне характеризующаяся аксиологическим смыслом. При этом «верх», наделенный в русской картине мира символическими признаками «хороший», «благополучный», «жизненный» [25], в восприятии город- 
ского пространства нечасто становится источником ценностного потенциала в мифологической модели мира горожанина. Напротив, именно осмысление «низа» как «плохого», «неблагополучного», «скудного», «смертельного» приводит к формированию особой мифологии хтонического. Термин «хтонизм» ввел в отечественную науку А.Ф. Лосев для обозначения культа земли и подземных сил. В рамках мифологизации городского пространства перемещение человека, идущего вниз, является семиотически значимым. Условный спуск вниз от некоторого меридиана субъективной городской картографии (трамвайные пути, центральная улица района, широкая проезжая часть) означает попадание в пространство плохого, т. е. не отвечающего ценностной картине мира носителя мифологического сознания. В избирательности мифологического восприятия города, которая формируется на основе предвзятых представлений о местности и её жителях, а также сигналов о социальном поведении, которые считываются в текущем физическом окружении, «плохой низ» выражен большими открытыми и безлюдными пространствами (запущенные парки, пустыри, реки), вокруг которых зачастую развивается локальная мифология; признаками бескультурья, такими как грязь и мусор, вандализм, граффити, подразумевающими, что неподобающее или угрожающее поведение возможно или разрешено. Пространственный переход отождествляется с переходом в локусы ненормативного состояния, в места девиантной социальности: «городской низ» символизирует упадок, моральное и интеллектуальное отставание, преступную деятельность, трансгрессивные сексуальности, субкультурные практики.

В реалиях Новокузнецка идея хтонического имеет существенные экономические и культурные последствия для городской социальности, поскольку вторым важным актантом в пространстве Новокузнецка, незначительно уступающим перед чувственной наглядностью и значимостью завода, является шахта.

Соответствующая деятельность, напрямую связанная с трансформациями твердой оболочки планеты, получает риторическое обрамление в соединении угля с архетипическими и фольклорными сюжетами. Нарушения угледобычи и сопровождающие их финансовые и человеческие потери актуализируют специфические образы, семантически схожие с мифом о ящике Пандоры или преданиями о наказании, посланном подземными божествами. Мортальность шахтерской деятельности фиксируется в неофициальной номинации Собора Рождества Христова, строительство которого в исторической действительности инициировано гибелью 67 шахтеров на шахте Зыряновская, как «церкви шахтерам».

Кроме того, конец жизни, гибель, смерть представлены семиотически через переосмысление «низа»: умирание локализовано не только на периферии городского пространства, ассоциированной с социальным низом, но и буквально внизу, на земле. Кладбище, как условный топос мортальности городской жизни, оказывается вне фокуса мифологического сознания, а в образе восприятия оказывается ненормативная смерть, когда мертвое тело находится в заброшенных зданиях или лежит на земле в темных густых зарослях, городских канонических «вратах» подобного рода переходов.

Как уже упоминалось, умершие олицетворяют собой загробный (хтонический) мир, в основе метафорического осмысления которого лежат религиозные представления о преисподней. Так, в восприятии жителя Новокузнецка условия производства на заводе восходят к представлениям об аде, воссоздавая его устойчивые культурные образы не только визуально и физически (пламя, искры, температуры), но и символически (в понимании места, превосходящего меру человеческих сил, чрезмерного, мучительного, невыносимого): «Ферросплавы [Металлургическое предприятие «Кузнечкие ферросплавы» - А.П.]: иеха ... ну, когда плавка идет, то есть там такие адские условия. 
Это завораживает, но, с другой стороны, ты понимаешь, как люди там работают. Они что-то там смеются, как-то абстрагируются, но это, реально, это ад на земле: там температура по 1200․ Они пробивают горны руками, когда у них вплоть до судорог - у молодых людей судороги начинаются, потому что сила нужна нечеловеческая, чтобы горн пробить <..> Потому что это очень адовый труд, то есть вот эти температуры ... там все эти искры летят» (Ж, 21, учеба).

В ментальной картографии горожанина хтоническое значение имеет мост как образ соединения различных планов существования «этого» мира с миром потусторонним. Покидая «домашние» пространства района проживания или центрального района города, в которых локализованы многие деятельности и взаимодействия практически каждого социально активного новокузнечанина (учеба, работа, места потребления и отдыха), житель через пересечение моста попадает в социально, эмоциональнопсихологически, а иногда и физически опасные места, в которых обыденный мир разрушается и появляется новый.

\section{Заключение}

Придерживаясь реляционного взгляда на природу городской жизни, пространство города может мыслиться как ситуационно-смысловая реальность, когда в каждой конкретной ситуации формируется личностный смысл элементов городской среды. Возникающий образ восприятия городского пространства является следствием логического осмысления и эмоционального переживания городской действительности, природноклиматической специфики, исторических событий, социокультурного бытия. В данной работе было показано, что абстрактное городское пространство получает субъективную размерность через усилия мифологического сознания. В этом случае миф становится пересечением двух семиотически концептуальных пространств: физического, географического и символического, семантического. Для исследования мифологического пространства современного российского города был реализован методологический потенциал подхода к мифу, который основан на совмещении семиотических и психоаналитических интерпретаций. Полученные результаты позволили увидеть не только континуум актуальных мифологических представлений о пространстве города Новокузнецка, но и идентифицировать, какое значение имеют пространственные содержания городской жизни для конституции социально-культурных действительностей. В первую очередь мифологии обеспечивают ориентацию в освоенном и неосвоенном пространстве, когда физическое освоение может быть приравнено к ментальному или воображаемому. В этом смысле конструирование в повседневном опыте горожанина относящихся к городскому пространству мифов и мифологий является продуктом систематического упорядочивания и классификации материи. Структурирующая сущность выявленных мифологий реализуется в формировании наших понятий о правильном миропорядке - о том, как должен выглядеть город, что и где можно делать в рамках городского пространства, что необходимо предпринять для гармонизации городской жизни. Преломленные через специфично мифологический тип сознания, представления горожан о месте своего обитания всегда оказываются попыткой возвращения к изначальным сущностям порядка, которые артикулированы в наиболее устойчивых кодах культурного дискурса. Особая смысловая конкретность и завершенность выражены в мифологии советского, оперирующей не просто разными представлениями о советском прошлом, но советским как символическим порядком. Мифология перехода и мифологическая актуализация хтонического представляют собой семантические инварианты, которые имеют архетипические основания и изначально ориентированы на управление 
стихийностью природы и жизни. Постижение красоты и подлинности в пространстве города, складывающееся в мифологию аутентичности и сопровождающееся эстетической и этической мифологизацией, восходит к гармонии и мере. Кроме того, идентификация с символическими проекциями любого коммуникативного кода культуры встраивает субъект в пространство собственного бессознательного, т. е. в пространство различных вытесненных культурой импульсов.

Через мифологии восприятия городского пространства обнаруживаются соотношения порядка и беспорядка, бытия и небытия, формы и бесформенности, жизни и смерти. Субъективная мифологическая модель городского пространства, возникающая и развивающаяся в координатах социокультурного контекста, становится условием целостного восприятия города при все большей фрагментарности и разобщенности отдельных сторон жизни современного человека.

\section{СПИСОК ЛИТЕРАТУРЫ}

1. Kümin B., Usborne C. At Home and in the workplace: a historical introduction to the «spatial turn» // History and Theory. 2013. - V. 52. - № 3. - P. 305-318.

2. Сертакова Е.А. Социокультурное пространство современного российского города (на материале анализа г. Красноярска): дис. ... канд. филос. наук. - Красноярск, 2015. - 172 с.

3. Мартишина Н.И. Мифологический компонент в конструировании образа города и городской идентичности // ПРАКСЕМА. Проблемы визуальной семиотики. - 2020. - № 3. - С. 168-178.

4. Агафонова А.Г. Реляционный подход в городских исследованиях // Журнал социологии и социальной антропологии. - 2015. - Т. XVIII. - № 4 (81). - С. 96-110.

5. Tuan Y.-F. Perceptual and cultural geography: a commentary // Annals of the Association of American Geographers. - 2003. - V. 93. - № 4. - P. 878-881.

6. Пирогов С.В., Петухов А.С. Феноменолого-когнитивная концепция города и её теоретические экстраполяции // Контекст и рефлексия: философия о мире и человеке. - 2017. - Т. 6. - № 3. - С. 120-130.

7. Harvey D. The sociological and geographical imaginations // International journal of politics, culture \& society. -2005 . - V. 18. - № 3-4. - P. 211-255.

8. Федотова Н.Г. Urban imaginary: визуальные маркеры городского воображаемого // ПРАКСЕМА. Проблемы визуальной семиотики. - 2020. - № 1. - С. 121-139.

9. Сойя Э. Постметрополис. Критические исследования городов и регионов // Логос. - 2003. - № 6 (40). C. $133-159$.

10. Осаченко Ю.С. Сущность мифа как философская проблема. 1. Феномен мифического: плюрализм интерпретаций // Известия Томского политехнического университета. - 2005. - Т. 308. - № 3. - С. 182-187.

11. Кузнецова А.В., Петрулевич И.А. Миф и мифологема города в тексте культуры: социологический и лингвокогнитивный аспекты // Известия вузов. Северо-Кавказский регион. Общественные науки. 2015. - № 4. - C. 32-36.

12. Головнёва Е.В. Мифологизация как способ конструирования городской идентичности (Екатеринбург на интернет-форумах) // Уральский исторический вестник. - 2016. - № 3 (52). - С. 43-51.

13. Miller D.L. Mything the study of myth // Jung Journal: Culture \& Psyche. - 2014. - V. 8. - № 4. - P. 14-25.

14. Барт Р. Мифологии / пер. с фр. С. Зенкина. - М.: Академический Проект, 2008. - 351 с.

15. Балюшина Ю.Л. «Город-завод»: проблема мифологизации индустриального города (на примере г. Череповца) // Kant. - 2018. - № 2 (27). - С. 156-160.

16. Фатнева О.В. О категории «другой» в структурном психоанализе // Вестник Томского государственного университета. - 2007. - № 302. - С. 58-61.

17. Печенина О.В. Функции реального, воображаемого и символического в коммуникативной модели структурного психоанализа Ж. Лакана // Вестник Санкт-Петербургского университета. - 2007. № 4. - C. 208-214.

18. Малая Е.К. Город как Другой: одушевление города в современной городской мифологии (психоаналитический аспект) // Проблемы современного образования. - 2016. - № 6. - С. 38-51.

19. Каганский В.Л. Культурный ландшафт и советское обитаемое пространство: сборник статей. - М.: Новое литературное обозрение, 2001. - С. 135-377. 
20. Соловьева А.Н. Концептуализация аутентичности в контексте глобализации культуры // Вестник Северного (Арктического) федерального университета. Серия «Гуманитарные и социальные науки». 2009. - № 2. - C. 137-141.

21. Пневски Д. Nео-возвышенное: современные толкования классической эстетики // Новый филологический вестник. - 2019. - № 2 (49). - С. 16-29.

22. Визуальная экология: формирование дисциплины: коллективная монография / под ред. В.В. Савчука. СПб.: Издательство РХГА, 2016. - 531 с.

23. Андрамонов Д.К. Конформизм и нонконформизм в обществе постмодерна (социально-философский анализ) : дис. ... канд. филос. наук. - М., 2016. - 164 с.

24. Геннеп А. Обряды перехода. Систематическое изучение обрядов / пер. с фр. - М.: Восточная литература, 1999. - $198 \mathrm{c}$.

25. Сабурова Н.А. Семиотическая оппозиция «верх/низ» в образном основании русских фразеологизмов // Вестник Приамурского государственного университета им. Шолом-Алейхема. - 2016. - № 2 (23). C. $29-40$.

Поступила 15.01.2021 г. 


\title{
URBAN SPACE AS A SEMIOTIC-MYTHOLOGICAL CONSTRUCT OF PERCEPTION: NOVOKUZNETSK MYTHOLOGIES
}

\author{
Alexandra E. Piskunova, \\ alexpiskunova@mail.ru \\ National Research Tomsk State University, \\ 36, Lenin avenue, Tomsk, 634050, Russia
}

\begin{abstract}
Alexandra E. Piskunova, master student, National Research Tomsk State University.
\end{abstract}
The relevance of the research is determined by sustained interest in the social sciences and humanities to understanding the spatial dimensions of urban life, the myth renewal as an important cultural reality of our time, as well as the need for understanding the practical problems of urban space perception, specific to Russian cities. The main aim of the study is to identify the myths and mythologies that determine the (mental) organization of urban space perception. The research methodology is based on a combination of a phenomenological and cognitive approach to understanding the image of urban space and compound of semiotic and psychoanalytic interpretations of the myth. The urban space seen in a relational perspective is described through cognitive-semantic structures that determine the selectivity of the perception process. Drawing on interviews with the residents of Novokuznetsk (Kemerovo region), collected by the author in April-August 2019, principal mythologies are analysed as entities resulting from the mythologization of urban space. Results. The article shows significance and role of the perception mythologies for creation of the spatial phenomena classification model of urban reality. The formed image of urban space is defined as a semantic structure and special «textual» reality that relevant to system of intersubjective significations and intrasubjective meanings of the urban view of the world. The results obtained made it possible to see not only the continuum of actual mythological representations of the Novokuznetsk urban space, but also to identify the significance of the spatial contents of urban life for the constitution of socio-cultural realities. It is identified that the myth-making activity of urban life subjects is an intention to a world order that meets the basic human requirements of stability and harmony.

Key words: Myth, mythology, urban space, construct, perception, Novokuznetsk.

\section{REFERENCES}

1. Kümin B., Usborne C. At home and in the workplace: a historical introduction to the «spatial turn». History and Theory, 2013, vol. 52, no. 3, pp. 305-318.

2. Sertakova E.A. Sotsiokulturnoe prostranstvo sovremennogo rossiyskogo goroda (na materiale analiza g. Krasnoyarska). Dis. Kand. nauk [Socio-cultural space of the modern Russian city (based on the analysis of the city of Krasnoyarsk). Cand. Diss.]. Krasnoyarsk, 2015. 172 p.

3. Martishina N.I. Mifologicheskiy komponent $\mathrm{v}$ konstruirovanii obraza goroda i gorodskoy identichnosti [Mythological component in the construction of the image of the city and urban identity]. PRAXEMA. Problemy vizualnoy semiotiki, 2020, no. 3, pp. 168-178.

4. Agafonova A.G. Relyatsionny podkhod v gorodskikh issledovaniyakh [Relational approach in urban studies]. Zhurnal sotsiologii i sotsialnoy antropologii, 2015, vol. XVIII, no. 4 (81), pp. 96-110.

5. Tuan Y.-F. Perceptual and cultural geography: a commentary. Annals of the Association of American Geographers, 2003, vol. 93, no. 4, pp. 878-881.

6. Pirogov S.V., Petukhov A.S. Fenomenologo-kognitivnaya kontseptsiya goroda i ee teoreticheskie ekstrapolyatsii [Phenomenological-cognitive concept of the city and its theoretical extrapolations]. Kontekst i refleksiya: filosofiya o mire i cheloveke, 2017, vol. 6, no. 3, pp. 120-130. 
7. Harvey D. The sociological and geographical imaginations. International journal of politics, culture \& society, 2005, vol. 18, no. 3-4, pp. 211-255.

8. Fedotova N.G. Urban imaginary: vizualnye markery gorodskogo voobrazhaemogo [Visual markers of the urban imaginary]. PRAXEMA. Problemy vizualnoy semiotiki, 2020, no. 1, pp. 121-139.

9. Soyya E. Postmetropolis. Kriticheskie issledovaniya gorodov i regionov [Postmetropolis: critical studies of cities and regions]. Logos, 2003, no. 6 (40), pp. 133-159.

10. Osachenko Yu.S. Sushchnost mifa kak filosofskaya problema. 1. Fenomen mificheskogo: plyuralizm interpretatsiy [The essence of myth as a philosophical problem. 1. The mythical phenomenon: pluralism of interpretations]. Izvestiya Tomskogo politekhnicheskogo universiteta, 2005, vol. 308, no. 3, pp. 182-187.

11. Kuznetsova A.V., Petrulevich I.A. Mif i mifologema goroda v tekste kultury: sotsiologicheskiy i lingvokognitivny aspekty [Myth and mythologem of the city in the text of culture: sociological and linguocognitive aspects]. Izvestiya vuzov. Severo-Kavkazskiy region. Obshchestvennye nauki, 2015, no. 4, pp. 32-36.

12. Golovneva E.V. Mifologizatsiya kak sposob konstruirovaniya gorodskoy identichnosti (Ekaterinburg na internet-forumakh) [Mythologization as a means of urban identity constructing (Ekaterinburg in internetforums)]. Uralskiy istoricheskiy vestnik, 2016, no. 3 (52), pp. 43-51.

13. Miller D.L. Mything the study of myth. Jung Journal: Culture \& Psyche, 2014, vol. 8, no. 4, pp. 14-25.

14. Bart R. Mifologii [Mythologies]. Translated from French by S. Zenkina. Moscow, Akademicheskiy Proekt, 2008. $351 \mathrm{p}$.

15. Balyushina Yu.L. «Gorod-zavod»: problema mifologizatsii industrialnogo goroda (na primere g. Cherepovtsa) [«City-factory»: the problem of mythologization of an industrial city (on the example of Cherepovets)]. Kant, 2018, no. 2 (27), pp. 156-160.

16. Fatneva O.V. O kategorii «drugoy» v strukturnom psikhoanalize [On the category «other» of the structural psychoanalysis]. Vestnik Tomskogo gosudarstvennogo universiteta, 2007, no. 302, pp. 58-61.

17. Pechenina O.V. Funktsii realnogo, voobrazhaemogo i simvolicheskogo v kommunikativnoy modeli strukturnogo psikhoanaliza Zh. Lakana [Function of the real, the imaginary and the symbolic in the communicative model of structural psychoanalysis (J. Lacan)]. Vestnik Sankt-Peterburgskogo universiteta, 2007, no. 4, pp. 208-214.

18. Malaya E.K. Gorod kak Drugoy: odushevlenie goroda v sovremennoy gorodskoy mifologii (psikhoanaliticheskiy aspekt) [The city as other: personification of a city in the current urban mythology (a psychoanalytic aspect)]. Problemy sovremennogo obrazovaniya, 2016, no. 6, pp. 38-51.

19. Kaganskiy V.L. Kulturny landshaft $i$ sovetskoe obitaemoe prostranstvo. Sbornik statey [Cultural landscape and Soviet habitable space]. Moscow, Novoe literaturnoe obozrenie Publ., 2001. pp. 135-377.

20. Soloveva A.N. Kontseptualizatsiya autentichnosti v kontekste globalizatsii kultury [Authenticity conceptualization in the cultural globalization context]. Vestnik Severnogo (Arkticheskogo) federalnogo universiteta. Seriya «Gumanitarnye $i$ sotsialnye nauki», 2009, no. 2, pp. 137-141.

21. Pnevski D. Neo-vozvyshennoe: sovremennye tolkovaniya klassicheskoy estetiki [The neo-sublime: modern interpretations of classical aesthetics]. Novy filologicheskiy vestnik, 2019, no. 2 (49), pp. 16-29.

22. Vizualnaya ekologiya: formirovanie distsipliny [Visual ecology: formation of discipline]. Kollektivnaya monografiya. Ed. by V.V. Savchuk. St. Petersburg, RHGA Publ., 2016. 531 p.

23. Andramonov D.K. Konformizm i nonkonformizm v obshchestve postmoderna (sotsialno-filosofskiy analiz). Dis. Kand. nauk [Conformism and nonconformism in postmodern society (socio-philosophical analysis). Cand. Diss.]. Moscow, 2016. 164 p.

24. Gennep A. Obryady perekhoda. Sistematicheskoe izuchenie obryadov [The rites of passage. Systematic study of rites]. Translated from French. Moscow, Vostochnaya literatura Publ., 1999. 198 p.

25. Saburova N.A. Semioticheskaya oppozitsiya «verkh/niz» v obraznom osnovanii russkikh frazeologizmov [Semiotic opposition up/down in the figurative phraseological base]. Vestnik Priamurskogo gosudarstvennogo universiteta im. Sholom-Aleykhema, 2016, no. 2 (23), pp. 29-40.

Received: 15 January 2021. 